DOI https://doi.org/10.18551/rjoas.2018-04.29

\title{
LOGISTIC OPERATIONS AND MANAGERIAL PERFORMANCE OF TABLE EGG ENTREPRENEURS IN AKWA IBOM STATE, NIGERIA
}

\author{
Ohen S.B., Ekaette M.N \\ Department of Agricultural Economics, University of Calabar, Calabar, Indonesia \\ *E-mail: drsbohen@gmail.com
}

\begin{abstract}
This study aims on logistic operations and managerial performance of table egg entrepreneurs in Akwa Ibom State. The specific objectives were to identify logistic operations used by table egg entrepreneurs in study area, and assess the managerial performance of table egg entrepreneurs and assess the effect of logistic operations on managerial performance of table-egg entrepreneurs. One hundred and eighty (180) table egg entrepreneurs were selected using the simple random sampling technique. Data were collected using structured questionnaires and analysed using descriptive statistics, Data Envelopment Analysis approach and multinomial logistic regression model. Findings of the study show that table egg entrepreneurs applied various logistic operations such as order handling $(91.1 \%)$, information sharing $(85 \%)$, inventory management $(84.4 \%)$, warehousing $(76.7 \%)$, packaging $(86.7 \%)$, product distribution scheduling $(66.1 \%)$ and transport coordination $66.1 \%$ ) in the production and distribution of table egg. However, the entrepreneurs were still found to perform below average as most $(89.4 \%)$ of them were within the efficiency scores of between $0-0.25$. Furthermore, only product distribution scheduling operation had a significant effect on managerial performance of table egg entrepreneurs in the study area. The study therefore recommended a collaborative approach between State and non-State actors in organizing capacity building trainings, workshops and seminars that will enhance the managerial capacities of table egg entrepreneurs in the study area. There is also need to set up monitoring and evaluation systems that will ensure that business operators effectively perform required logistic operations that will enhance their overall performance in business.
\end{abstract}

\section{KEY WORDS}

Table egg, managerial performance, logistic operations, business.

The business of poultry farming comprises chickens, turkeys, geese, ducks, quail and guinea fowls. Chickens constitute about $70 \%$ of the poultry population in Nigeria therefore the term 'poultry farming' is used generally to refer to chicken farming in Nigeria (Ojo, Ojo, Jirgi and Ajayi, 2012). The major poultry products are eggs and meat. Binuomote et al. (2008). However, FAO, (2008) enumerated the advantages of table egg over meat and other sources of animal protein to include the point that egg is one of the most nutritious and complete foods known to man because it has biological value of 1.0 , contains $6 \mathrm{~g}$ of protein and so shares with human protein the distinction of being a perfect protein. According to Olagunju, (2007) and Amos, Chikwendu, and Nmadu, (2004), egg contains substantial amount of vitamins $A$ and $D$, thiamin and riboflavin. It ranks only with cow whole milk as the most economically produced animal protein. Eggs can be used for industrial purposes namely: confectionery, bakery products, ice cream, cosmetics, hair shampoo, custard and beverages. Egg shell can also serve as a good source of calcium (Tijani, Alimi, and Adesiyan, 2006). Egg production is a major index of performance of poultry business in Nigeria. Alabi \& Aruna (2005) reported that egg accounts for about $90 \%$ of the income from poultry industry. Table egg production is a very profitable business but the negligence of the necessary management routine can make the venture to be unprofitable (lyangbe and Orewa, 2009).

In recognition of the importance of poultry industry and table egg in particular, successive governments in Nigeria have sought to rejuvenate the subsector since the late 
1990s by investing in research and development projects. The National Animal Production Institute is a publicly funded research center that studies poultry production practices and technologies and has developed an improved poultry breed for the country. The National Veterinary Research Institute is responsible for diagnosing and investigating poultry diseases and developing vaccines. With support from the UN and World Bank, the facility undertook upgrades following the emergence of Avian Influenza in Nigeria and now serves as the designated Avian Influenza laboratory for West and Central Africa.

Other government policies supporting the domestic poultry sector include reducing tariffs on imported poultry vitamins and vaccines, subsidizing Newcastle disease vaccines for rural producers, and supporting the Presidential Initiative on Livestock, which sought to increase production, consumption, and export of poultry and other animal products. The initiative ran from 2004 to 2006 and was intended to help smallholder and commercial producers through feed and nutrition, veterinary, and marketing and processing interventions. An analysis by the Pro-Poor Highly Pathogenic Avian Influenza group noted that the initiative's ideas and goals were worthwhile.

However, Afolabi, (2012), lyangbe \& Orewa, (2009) and Adepoju (2008) reported that poultry industry has performed below expectation in recent times. They attributed this development to inefficiency in resource use. They also described the business environment of egg producing enterprises as hostile due to: high cost of feed, poor management, diseases and pests, poor extension and training facilities, marketing problems, lack of credit facilities, poor logistics and lack of regulatory institutions to ensure that farmers comply with established rules for quality, products safety and standard.

Furthermore, firms are expected to perform some logistic operations (order handling, information sharing, product distribution scheduling, inventory management and control, transportation, packaging and warehousing) along the distribution channel linking suppliers, manufacturers and end consumers. According to Sakchuchawan et al., 2011 firm owners that utilize these operations perform more efficiently in management. Studies show that adoption of logistic innovations could impact positively on the development of business firms (Sakchutchawan and Hong, 2011), (Graebner and Eisenhardt, 2010) (Chen and Hsueh, 2009) and (Kongmanilaa, Xayphone, and Takahashib, 2009).

Despite reports that logistic operations could impact positively on the development of agribusiness (Sakchutchawan and Hong, 2011), (Graebner and Eisenhardt, 2010) (Chen and Hsueh, 2009) and (Kongmanilaa, Xayphone, and Takahashib, 2009), there is still paucity of information on the logistic operations utilized by table egg entrepreneurs in Akwa Ibom State. Also information on how these operations impact on their managerial performance is lacking. The importance of table egg business in Akwa Ibom State cannot be overemphasized as the State is a major distributor of table eggs within the South South and South East regions for the country. The lack of information on logistic operations and how the impact on managerial performance of table egg entrepreneurs therefore presents a research gap which this study sought to address.

The general objective of this study was to assess logistic operations and managerial performance of table egg entrepreneurs in Akwa Ibom State.

The specific objectives of the study were to:

- Identify logistic operations practiced by table egg entrepreneurs in study area;

- Assess the managerial performance of table egg producers using managerial efficiency scores;

- Ascertain the effect of logistic operations on managerial performance of table-egg producers.

$\mathrm{H}_{01}$ : Logistic operations of table egg entrepreneurs have no significant effect on their managerial performance.

\section{LITERATURE REVIEW}

Logistic operations in agribusiness firms. Logistic operations encompasses many activities, including order handling, information sharing, product distribution scheduling, 
inventory management and control, transportation, packaging and warehousing. Innovation in logistics is fundamental to an organization, which can be implemented in internal activities or services. Such an innovation could enhance the coordination capabilities among channel activities, which enables firms to avoid dysfunctional operational performance and other negative consequences, such as higher inventory costs, longer delivery times, higher transportation costs, and other disadvantages (Sakchuchawan et al., 2011).

Many studies support the significant impact of logistics innovation on firm performance. Sakchuchawan et al. (2011) found that logistics as part of the supply chain system provides benefits in terms of time and place utilities; and hence it is able to enhance firm performance.

Order handling. Order handling is recognized as one of the decisive factors for business processes in most profit-oriented company (Landes, 2008). It is the main logistics activity that smoothens the movement of goods or products and services (Kuswantoro and Rosli, 2012).

The important role of order handling innovation in firm's logistics efficiency is also emphasized by many researchers. According to Graebner et al. (2010), the application of technological support, such as radio-frequency identification and global positioning system will enhance real-time tracking information for products and replacement orders within the value chain.

Information sharing. An effective information sharing system is vital for achieving distribution channel performance (Zhou and Benton, 2007). Having a good coordination among independent channel members, such as raw material suppliers, manufacturers, distributors and retailers enables the players to enhance logistic processes within the rapid change in market conditions (Diehl and Poynor, 2010).

Kongmanilaa, et al. (2009) found that the significant success factor for export-oriented SMEs was contingent upon the capability of the firms to manage their relationship with foreign importers. With the advent of information technology, information can be processed, transmitted and collected at a faster rate. As a result of this technological revolution, market knowledge of the firms and their relationship with the channel members within the value chain system has tremendously improved which in turn enhanced firm performance (Fernandez, 2006),

Inventory management. Inventory forms a significant part of current asset of an enterprise. A good inventory management system is a decisive factor for a firm's success (Linda, Zhang, \& Qinhai, 2009). On the contrary, inaccuracy in inventory management would create a range of problems, such as productivity loss, unwanted items of manufacturing, a reduction in the customer commitment level, and increased costs. Thus, the cost savings accumulated from improved practices in inventory management is remarkable (Morgado, 2008).

The linkages between inventory management and competitive advantage, such as cost, delivery, and quality are significant (Rosli, 2012). An innovation in inventory management and control is crucial for a firm. It allows an enterprise not only to minimize inventory costs, but also to avoid direct consequences due to the shortage of material resources which directly affect distribution activities (Mukhamad \& Kiminami, 2011).

Product distribution scheduling. Product distribution scheduling is a logistic activity, concerned about when and where the collection of goods should be formed and delivered (Lee and Kim (2010). A product scheduling method, which is coupled with material supply and product delivery, will improve logistics efficiency (Chen and Hsueh, 2009). Innovation in product distribution scheduling was discovered to be able to improve efficiency as well (Somuyiwa, 2007). Furthermore, the identification of the optimal production quantities, the time to produce and the vehicle routes through a computerized method is the effective and efficient way to increase total profit (Chen and Hsueh, 2009). A new method of polynomialtime algorithms in solving product distribution scheduling was found to be able to minimize inventory and transportation cost (Chen, 2009). Besides directly enhancing logistics efficiency, such an innovation will ultimately affect firm performance.

Transport coordination. The role of transportation system is crucial in a distribution channel system because it could provide more efficient logistics, reduce operational costs, 
and promote the service quality. According to Major (2008), transportation costs, on average, accounted for 44 percent of the total logistics costs. Therefore, an innovation in transportation coordination methods using the three major elements of smart transportation management (smart goods, smart vehicles and smart infrastructure) would bring about a positive impact on logistics performance (Sakchutchawan et al, 2011). In other words, the well-operated logistics system would increase the competitiveness of enterprises (Tadeusz, 2009). In contrast, a poor coordination of the logistics system would lead to higher costs, longer delivery times, higher levels of loss and damage, and poor customer service (Schacht, 2010; Sánchez and Popescy, 2011).

Packaging. Packaging serves as a tool for product promotion and use. While packaging engineers see packaging as a protective device only, distribution managers perceive packaging in a broader perspective. To the latter, any changes in design, size, and media of transportation would contribute to the efficiency of a distribution system (Wang et al, 2009). A recent study on 800 U.S. shoppers in eight product categories demonstrated that innovation in new packaging systems directly affected price expectation and product selection among the shoppers (Lee et al, 2010). The study found that if packaging is done properly, it is very likely provides a positive return on investment (ROI) through increased market share or the ability to raise prices to cover incremental costs.

Warehousing. Warehousing creates time utility for prospective customer (Diehl and Poynor, 2010). Finished goods or material handling in the logistic system is concentrated in and around the warehouse facility. The absence of goods in the warehouse means the interruption of the goods flows, which will add costs to transactions. To avoid this interruption, some technologies can be adopted. Such technologies could improve distribution performance in warehousing and finished good handling, which in turn leads to firm performance (Diehl and Poynor, 2010).

\section{METHODS OF RESEARCH}

Study area. Akwa Ibom State lies between Latitude $4^{\circ} 32^{\prime}$ and $5^{\circ} 32^{\prime}$ North and Longitude $7^{\circ} 25^{\prime}$ and $8^{\circ} 25^{\prime}$ east of the equator. The state is bordered to the West by River State and Abia and Imo State in the North, Cross River State in the East and Atlantic Ocean forming its southern boundary (Inyang, 1989). The State occupies an area of 8,412 square kilometers with a population of 3.9million based on the national census figure of year 2006 and an average population density of 350 inhabitants per square kilometer with 85 percent of the population living in rural areas (NBS, 2008). There are thirty-one Local Government areas in the state. The rich land mass and all year-round clement weather offer a favourable environment for wildlife conservation, the production of food and tree crops, fish and livestock farming.

Sampling procedure and data collection. Simple random sampling was used to select 210 table egg firms from a sampling frame of 1,051 table egg firms in the 6 agricultural zones in Akwa Ibom State. The frame was obtained from the Livestock Department, Ministry of Agriculture and Natural Resources, Akwa Ibom State. The owners/managers/producers of the selected firms were then used as respondents for this study.

Data collection. The study used structured questionnaire to elicit information from the selected table egg entrepreneurs. Information collected were on the socio-economic characteristics of table egg entrepreneurs, variable and fixed costs of table egg production and logistic functions practiced by table egg entrepreneurs. .One hundred and eighty questionnaires (180) out of the 210 firm owners selected returned their filled and completed questionnaire. Hence, data was analysed using 180 respondents. .

Analytical framework. Descriptive statistics such as frequency counts and percentages to describe the logistic operations practiced by table egg entrepreneurs. Data Envelopment Analysis (DEA) model was used to determine the managerial performance. Managerial efficiency was used is an indicator for an entrepreneurs' managerial performance. Also, a multinomial logistic regression was fitted to analyse the effect of selected logistic operations on managerial performance (efficiency). 
Managerial performance using Data Envelopment Analysis. Data envelopment analysis (DEA) is a technique developed in operations research and management science for measuring efficiency of decision making units (DMUs). It is a non-parametric methodology, pioneered by Charnes et al. (1978), used for estimation of efficiency, ranking production units on the basis of their performances and benchmarking of DMUs for efficient performance.

The model aims at evaluating the relative efficiencies of comparable decision making units (DMUs) by means of a variety of mathematical programming models. It involves the use of technical linear programming to construct a non-parametric piecewise surface (or frontier) over data, and also to enable the calculation of an efficient firm relative to its surface (Coelli, 1996a). Two DEA models developed by Charnes et al. (1978) namely: the Charnes, Cooper and Rhodes (CCR) model which consider constant returns to scale (CRS) and the Banker, Charnes and Cooper (BCC) model which considers variable return to scale (VRS) were used to calculate the managerial efficiency which is an indicator for firm performance.

An input oriented CCR model is given below:

$$
\begin{aligned}
\max W_{P} & =\sum_{r=1}^{s} u_{r} y_{r p} \\
\text { s.t: } & \sum_{i=1}^{m} v_{i} x_{i p}=1
\end{aligned}
$$

Model 1:

$$
\begin{aligned}
& \sum_{\substack{r=1 \\
u_{r}, v_{i} \geq 0}}^{s} u_{r} y_{r j}-\sum_{i=1}^{m} v_{i} x_{i j} \leq 0 \quad \forall j, \\
& \forall i, r .
\end{aligned}
$$

Likewise, the BCC model is formulated as follows (Model 2):

$$
\max W_{P}=\sum_{r=1}^{s} u_{r} y_{r p}
$$

Model 2:

$$
\begin{aligned}
& \sum_{r=1}^{s} u_{r} y_{r j}-\sum_{i=1}^{m} v_{i} x_{i j} \leq 0 \quad \forall j, \\
& u_{r}, v_{i} \geq 0 \\
& \forall i, r .
\end{aligned}
$$

Model 1 (input oriented CCR model) allowed table-egg farms [otherwise referred to as Decision Making Units (DMUs) in DEA terminology] that had low inputs to come up with increasing returns to scale whereas model 2 (BCC model- output oriented model) allowed DMUs that had high inputs would come up with decreasing returns to scale.

Input-oriented model focuses on reducing inputs in order to have a $100 \%$ efficient DMU while the output-oriented model focuses on increasing outputs to have an efficient DMU.

$\mathrm{n}=$ Number of table egg farms otherwise called decision-making units (DMUs).

$\mathrm{m}=$ Socioeconomic factors that can influence managerial efficiency of table egg producers namely: age of the manager (yrs), access to extension services, (dummy, yes $=1$; No = 0); years of experience (yrs); access to credit (dummy, yes $=1$; No $=0$ ); household size (No); educational qualification of table egg producers (years of schooling), estimated per production cycle $(\mathrm{N})$, etc to produce table egg.

$\mathrm{s}=$ Quantity of outputs (table-egg) produced by each DMU.

Specifically, DMUj consumes amounts xij $(i=1, \ldots, m)$ from inputs to produce amounts yrj $(r=1, \ldots, s)$ of outputs (table-eggs). 
In the model formulation, $\operatorname{xip}(i=1, \ldots, m)$ and $y r p(r=1, \ldots, s)$ denote the nonnegative crisp vectors of input and output values for DMU $p$ and $v$ and $u$ symbolize input and output weights, respectively. In solving an optimization problem, each DMUj sets its own weights to maximize its efficiency subject to the condition that all efficiencies of other DMUs remain less than or equal to (1) and the values of the weights are greater than or equal to (0) (Komleh et al., 2011). For the best situations, an efficiency value of (1) indicates a managerially efficient unit (entrepreneur) (Dagistan et al., 2009).

Effect of Logistic operations on managerial performance of table-egg entrepreneurs. Logistics functions investigated in this study included order handling, information sharing, inventory, warehousing, packaging, product distribution scheduling and transportation coordination. Table egg entrepreneurs were asked to indicate whether they performed these logistic functions in their farm operations or not.

A multinomial logistic regression to ascertain the effect of logistic functions on managerial performance. The multinomial logistic regression equation is given by:

$$
\begin{aligned}
& \ln \left(\frac{\pi_{1}}{\pi_{k}}\right)=\alpha_{1}+\beta_{11} X_{1}+\beta_{12} X_{2}+\cdots+\beta_{1 p} X_{p}, \\
& \ln \left(\frac{\pi_{2}}{\pi_{k}}\right)=\alpha_{2}+\beta_{21} X_{1}+\beta_{22} X_{2}+\cdots+\beta_{2 p} X_{p}, \\
& \vdots \\
& \ln \left(\frac{\pi_{k-1}}{\pi_{k}}\right)=\alpha_{k-1)}+\beta_{(k-1) 1} X_{1}+\beta_{(k-1) 2} X_{2}+\cdots+\beta_{(k-1) p} X_{p},
\end{aligned}
$$

Where: $\pi_{j}=\mathrm{P}(y=j)$ is the probability of an outcome being in category $j, k$ is the number of response categories, and $p$ is the number of predictor variables.

Dependent variable specification. Managerial performance (the managerial efficiency scores were used as dummy variables respondents within 0-0.25 managerial efficiency score $=1$, respondents within $0.26-0.5$ managerial efficiency score $=2$, respondents within $0.51-0.75$ managerial efficiency score $=3$ and respondents within 0.76-1.0 managerial efficiency score $=4$

Predictor Variables and their measurements:

$\mathrm{X}_{1}=$ (dummy variable) [Yes=1(if the table egg entrepreneur practiced order handling, 0 if otherwise]

$\mathrm{X}_{2}=$ (dummy variable) [Yes $=1$ if the table egg entrepreneur practiced information sharing, 0 if otherwise]

$\mathrm{X}_{3}=$ (dummy variable) [Yes=1(if the table egg entrepreneur practiced inventory management, 0 if otherwise]

$\mathrm{X}_{4}=$ (dummy variable) [Yes=1(if the table egg entrepreneur practiced warehousing, 0 if otherwise]

$\mathrm{X}_{5}=$ (dummy variable) $[Y e s=1$ (if the table egg entrepreneur practiced packaging operation, 0 if otherwise]

$\mathrm{X}_{6}=$ (dummy variable) [Yes=1(if the table egg entrepreneur practiced product distribution scheduling, 0 if otherwise]

$\mathrm{X}_{7}=$ (dummy variable) [Yes $=1$ (if the table egg entrepreneur practiced transportation coordination, 0 if otherwise]

\section{RESULTS AND DISCUSSION}

Logistic operations used by table egg entrepreneurs in the study area. The frequency distribution on the logistic operations used by table egg entrepreneurs in the area of study is presented in Table1. The result shows that most of the respondents have applied one form of logistic function or the other in running of their businesses. Over Ninety one percent $(91.1 \%)$ of the table-egg entrepreneurs had used order handling. Information sharing (85\%), inventory management $(84.4 \%)$, warehousing $(76.7 \%)$, packaging $(86.7 \%)$, product distribution scheduling $(66.1 \%)$. While $66.1 \%$ had applied transport coordination. 
Table 1 - Logistic operations used by table egg entrepreneurs in the study area

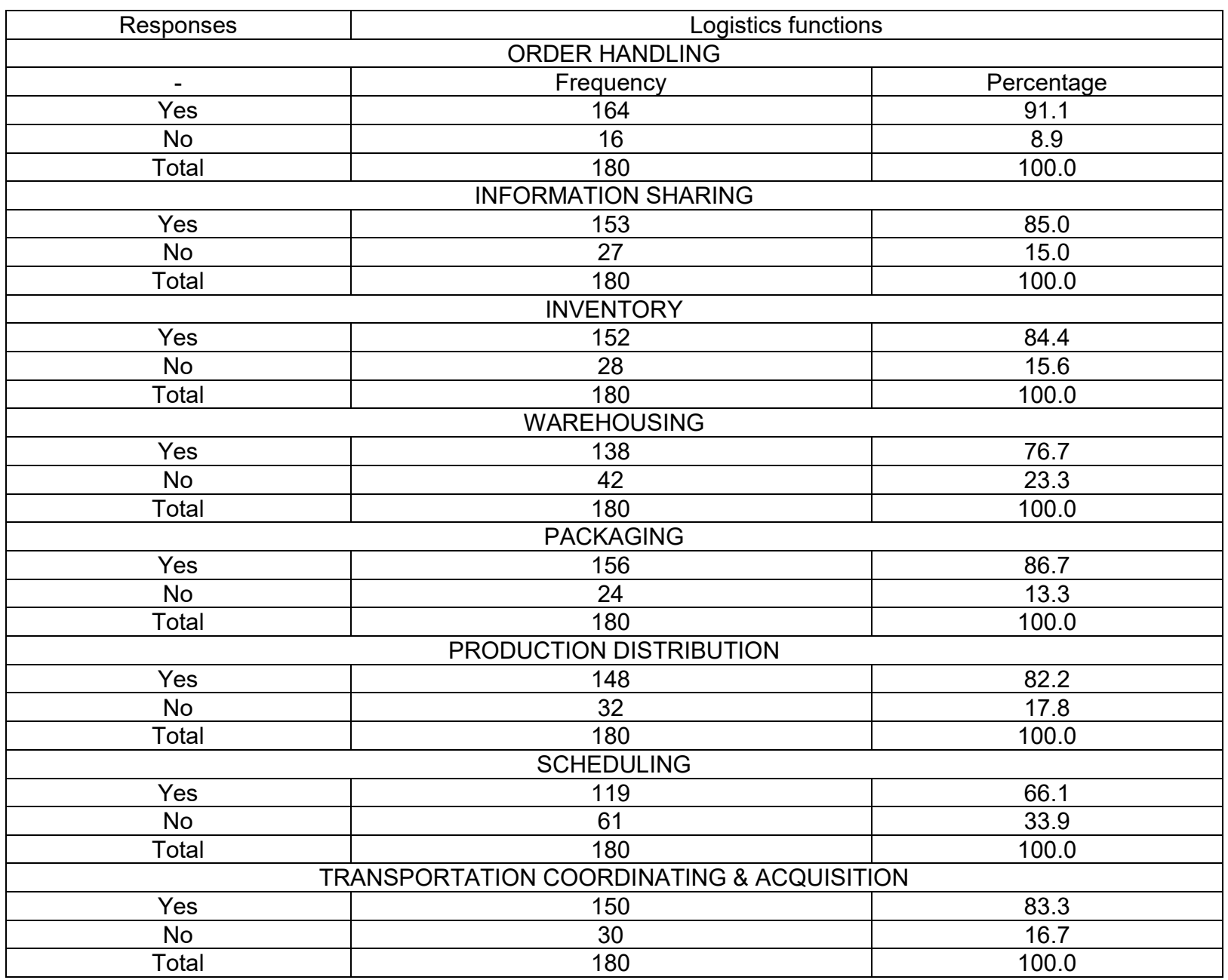

Managerial performance of table egg entrepreneurs. In terms managerial performance the efficiency scores calculated using the DEA approach show that $89.4 \%$ of the respondents had managerial efficiency score of between $0-0.25$ while $2.2 \%$ of respondents accounted for managerial efficiency score of $76-100$. The minimum managerial efficiency of table egg firms was $2 \%$ while the maximum was $100 \%$. The average managerial efficiency score was $12.6 \%$, with standard deviation of $16.1 \%$. The scores show that the entrepreneurs were managerially inefficient which implies that the firms in the study area performed below average in the management of their enterprise. Efficiencies scores orientated towards one (1) are more desired. And only $2.2 \%$ of the table egg firms operated within the region of 0.76 1.0 (Table 2).

Table 2 - Managerial Efficiency levels of table egg producers

\begin{tabular}{lll}
\hline Managerial efficiency scores & Frequency & Percentage \\
\hline $0-0.25$ & 161 & 89.4 \\
$0.26-0.5$ & 12 & 6.7 \\
$0.51-0.75$ & 3 & 1.7 \\
$0.76-1.0$ & 4 & 2.2 \\
Total & 180 & 100 \\
Mean & $12.6(16.1)$ & \\
\hline
\end{tabular}

Source: Field Survey (2016). Note: Figures in parentheses are std. deviations.

Effect of logistics operations on managerial performance. The result showed that product distribution scheduling contributed significantly to managerial performance of the table egg entrepreneurs in the study area. This implied that table-egg entrepreneurs who 
used product distribution scheduling technique were likely to perform better than those who did not. This is in line with Kongmanilaa, Xayphone, \& Takahashib, 2009; Graebner \& Eisenhardt, 2010 and Sakchutchawan \& Hong, 2011 who opined that product distribution is an ancillary to trade and ensures increases in sales and efficiency. Other logistic operations did not significantly explain changes in managerial performance (Table 3).

Table 3 - Multinomial logistic regression on the effect of logistics functions on managerial performance of table egg producers

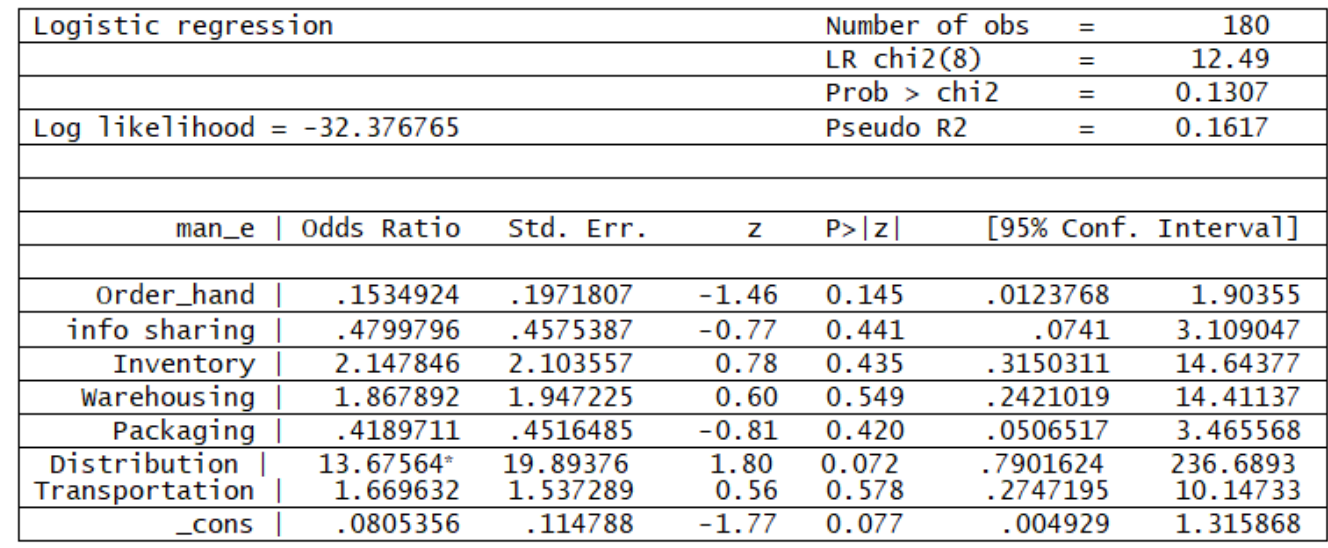

Order_hand = order handling, info sharing=information sharing, Inventory=inventory management, Distribution= product distribution scheduling, Transportation= transportation coordination.

\section{CONCLUSION}

Although over $70 \%$ of table egg entrepreneurs claimed to have applied the various logistic operations namely: order handling (91.1\%), information sharing (85\%), inventory management $(84.4 \%)$, warehousing $(76.7 \%)$, packaging $(86.7 \%)$, product distribution scheduling $(66.1 \%)$ and transport coordination $66.1 \%)$ in the production and distribution of table egg, the positive effects which these operations have been reported to have on the managerial performance as reported scholars were not evident in this study. Only product distribution scheduling had a significant effect on managerial performance of table egg entrepreneurs in the study area. This is an indication of the poor managerial capacity of the table egg entrepreneurs. The study recommends a collaborative approach between state and non-state actors in organizing capacity building trainings, workshops and seminars for table egg entrepreneurs in the study area. These would raise the present low capacities of table egg producers, enhance proper utilization of resources used in table egg production, expose table egg producers to best management practices and proper applications of various logistic operations, stimulate investments and create conducive business environment for operators within the value chain. There also need to set up monitoring and evaluation systems that will ensure that business operators effectively perform required logistic operations that will enhance their overall performance in business.

\section{REFERENCES}

1. Adepoju, A.A. (2008). Technical efficiency of egg production in Osun State. International Journal of Agricultural Economics and Rural Development. 8:7-14

2. Afolabi O. I. (2012).Credit Constraints and Production Efficiency in Poultry (Egg) Farming in Ogun State. Nigeria. An Unpublished M. Agric. Dissertation Work Submitted to the Department of Agricultural Economics and Farm Management. College of Agricultural Management and Rural Development. Federal University of Agriculture Abeokuta, Ogun State. Nigeria,.34-35

3. Alabi, R. A. and Aruna, M. B. (2005) Technical efficiency of family Poultry Production in Niger Delta, Nigeria', Journal of Central European Agriculture, 6(4): 531- 538. 
4. Amos, T. T., Chikwendu, D. O., \& Nmadu, J. N. (2004). Productivity, technical efficiency andcropping patterns in the savanna zone of Nigeria. Journal of Food, Agriculture and Environment, 2(2): 173- 176.

5. Binuomote, S.O., Ajetomobi, J.O and Ajao, A.O. (2008). Technical efficiency of poultry egg producers in Oyo State, Nigeria. International Journal of Poultry Science. 7:12271231

6. Charnes, A., Cooper, W.W. and Rhodes, E. (1978), 'Measuring the efficiency of farms', European Journal of Operational Research, 2: 429-444.

7. Chen, H.K. \& Hsueh, C.F. (2009). Production scheduling and vehicle routing with time windows for perishable food products. Computers \& amp Operations Research, 36(7): 2311-2319

8. Dagistan, E., B. Koc, M. Gul, O. Parlakay \& M.G. Akpinar,(2009) Identifying technical efficiency of dairy cattle management in rural areas through a non-parametric method: a case study for the east Mediterranean in Turkey, Journal of Animal and Veterinary Advances, 8: 863-867.

9. Diehl, K. \& Poynor, C. (2010). Great expectations?! Assortment size, expectations, and satisfaction. Journal of Marketing Research, XLVII, 312-322.

10. FAO, (2008) Food and Agriculture Organisation, Household metal silos key allies in FAO's fight against hunger. Rome: Agricultural and Food Engineering Technologies Service, FAO., 456-478

11. Fern'andez, M. I. J. N. Z. (2006). The role of information technology in corporate strategy of small and medium enterprises. Journal of International Entrepreneurs. (3) 251-262

12. Graebner, M. E. and Eisenhardt, K. M., (2010). Success and failure in technology acquisitions: Lessons for buyers and sellers. Journal of Academy of Management Perspectives, 24(3): 73-92

13. lyangbe, C. O., \& Orewa, S. I. (2009). Determinants of daily protein intake among rural and low-income urban households in Nigeria. American-Eurasian Journal of Scientific Research, 4(4), 290-301.

14. Komleh S.H., Pishgar, M. Omid, A. Keyhani,(2011), Study on energy use pattern and efficiency of corn silage in Iran by using Data Envelopment Analysis (DEA) technique, International Journal of Environmental Sciences, 1(6): 1094-106.

15. Kongmanilaa, Xayphone, and Takahashib, Y. (2009). Innovation, export performance and profitability of Lao garment exporters. International Journal of Economics and Management, 3(2), $225-236$.

16. Kuswantoro, F. \& Rosli, M.M. (2012) Logistics efficiency and firm Performance: Evidence from Indonesian small and medium enterprises, American International Journal of Contemporary Research, 2 (6):102-112

17. Landes, M. (2008). The environment for agricultural and agribusiness investment in India. Economic Information Bulletin No. 37. Washington, DC, USDA.

18. Lee, S.S. and. Kim, Y. (2010). The impact of efficiency parameters on firms' innovative activities: Evidence from Korean firm-level data. Innovation: Management, Policy \& Practice. 12(3), 283-297.

19. Linda L. Zhang, R. J. J., \& Qinhai, M. (2009). Accountability-based order fulfillment process reengineering towards supply chain management. Journal of Manufacturing Technology Management, 21(2), 287-305.

20. Major, I. (2008). Technical efficiency, allocative efficiency and profitability in Hungarian small and medium-sized enterprises: A Model with frontier functions. Journal of EuropeAsia Studies, 60(8): 1371-1396.

21. Morgado, A. (2008). Ceeman case study logoplaste: Innovation in the global market from packaging to solution. Journal of Management Decision. 46(9): 1414-1436.

22. NBS, (2008) National Bureau of Statistics, Statistical Bulletin, 2008.

23. Ojo M.A., Ojo A.O., Jirgi A.J. \& Ajayi O.J. (2012),Non-parametric analysis of production efficiency of poultry egg farmers in delta state, Nigeria. British Journal of Poultry Sciences, 1(2): 18-24 
24. Olagunju, F. I. (2007). Cost and returns on egg production in southwestern Nigeria, Research Journal of Applied Sciences, 2(2):160-164.

25. Rosli, M. M., Ferri K., and Ahmad R.C.O.(2012). Competitive strategies and firm performance: A comparative study of Malaysian and Indonesian small and medium enterprises. 3rd International conference on business and economic research (3rd ICBER 2012), 460-474

26. Sakchutchawan, S., \& Hong, P.C. (2011). Innovation and competitive advantage: Model and implementation for global logistics. International Business Research, 4(3):10-21.

27. Sánchez, A. G., \& Popescy, D. (2011). How to improve small and medium-sized enterprises profitability by practicing an efficient human resources management. Theoretical \& Applied Economics, 18(1): 49-64.

28. Schacht, D. (2010), Maize transport and logistics: preliminary findings, Washington, DC: USAID, 116-18

29. Somuyiwa, A.O (2007).The Relationship between the concepts of logistics and distribution in Nnadi, K.U. and Ogwude I.C (ed) Transportation in Nigeria: Economics, Policy and Management. Owerri: Reliable Publisher, Nigeria, 78-80.

30. Tadeusz, S. (2009). Coordinated supply chain scheduling. International Journal of Production Economics, 120(2): 437-451.

31. Tijani, A. A., Alimi, T., \& Adesiyan, A. T. (2006). Profit Efficiency among nigerian poultry egg Farmers. Research Journal of Agricultural and Biological Sciences, 2(6): 256-261.

32. Wang, X. \& Cheng, T.C.E., (2009). Logistics scheduling to minimize inventory and transport costs. International Journal of Production Economics, 121(1): 266-273.

33. Zhou, H. \& Benton Jr W.C., (2007). Supply chain practice and information sharing. Journal of Operations Management, 25(6: 1348-1365. 